FISCAL POLICY INSTRUMENTS AND THE POLITICAL ECONOMY OF DESIGNING PROGRAMS TO REACH THE POOREST

Ehtisham Ahmad

Asia Research Center and IMF

Asia Research Centre Working Paper 25 


\title{
Fiscal Policy instruments AND THE POLITICAL ECONOMY OF DESIGNing Programs to REACH THE POOREST
}

\begin{abstract}
Written by: Ehtisham Ahmad ${ }^{1}$
Ehtisham Ahmad is Senior Advisor at the IMF and Associate Fellow of the Asia Research Center (ARC), at the London School of Economics. Dr. Ahmad has held senior positions over the past two decades in the International Monetary Fund (Senior Advisor, Office of Executive Directors; Advisor and Division Chief, Fiscal Affairs Department); and was also a member of the core team for the World Bank's 1990 World Development Report on Poverty. He has also been Special Advisor to the Finance Minister of Saudi Arabia; as well as Director of the Development Economics Research Program, STCERD, LSE in the late 1980s, and Deputy Director of the Development Economics Research Center at the University of Warwick (to 1986). He has written extensively on public economics and federalism--his books include, inter alia: "Theory and Practice of Taxation", (with Nicholas Stern), "Social Security in Developing Countries," (with Jean Dreze, John Hills and Amartya Sen), and more recently "Handbook of Fiscal Federalism" and "Does Decentralization enhance Service Delivery and Poverty Reduction" (with Giorgio Brosio).
\end{abstract}

Copyright (C) Ehtisham Ahmad 2009

Email: eahmad@imf.org

All rights reserved. Apart from any fair dealing for the purpose of research or private study, or criticism or review, no part of this publication may be reproduced, stored in a retrieval system or transmitted in any form or by any means without the prior permission by the publisher or author.

For further information, please contact

Asia Research Centre (ARC)

London School of Economics \& Political Science

Houghton Street

London WC2A $2 \mathrm{AE}$

www.lse.ac.uk/collections/asiaResearchCentre

\footnotetext{
${ }^{1}$ Forthcoming in Ehtisham Ahmad and Giorgio Brosio (eds), Does decentralization enhance service delivery and poverty reduction? Edward Elgar (forthcoming). Earlier versions were presented at a conference in Beijing in October 2007, on "Reaching the Poorest," organized by the Chinese Leading Group on Poverty Reduction of the State Council and the International Food Policy Research Institute. The views expressed are personal and do not necessarily reflect those of the IMF. Helpful discussion with Giorgio Brosio, Mercedes García-Escribano, Stuti Khemani, Jean-Phillipe Platteau, Ugo Panizza and Joachim von Braun are acknowledged.
} 


\section{A. The Context}

Reaching the poorest and hungry groups of the population, including those who might be left out of the Millennium Development Goals (MDGs) involves policy makers at the central and local levels of government. While there has been considerable focus on appropriate targeting mechanisms to reach the poor (see e.g., World Bank 1990, Besley and Kanbur, 1993), attention as to which level of government should be involved, as well as the interactions between levels of government in reaching the poor, is more recent (see von Braun and Grote, 2002, Bardhan and Mookherjee, 2000 and a survey by Birner, 2007).

From the policy perspective, it is important to examine the instruments available at each level of government in order to meet the needs of the poorest. If the responsibility for these groups is seen primarily as that of the central government, then direct federal/central government programs, effectively targeted but building on local information come into focus. If the primary responsibility is local, the policy focus shifts to own-source revenues for financing the expenditures and for greater local accountability, together with a modicum of equalization transfers so that all local governments have similar capacities to provide for the poorest.

Designing central programs to reach the poorest may be difficult without local information. This is because the central government, particularly in large countries such as Mexico and China, lacks the ability to precisely define marginal groups or households that may not benefit from more general growth and prosperity. Yet local officials may not share the objectives of the center-and may prefer to divert central funds to meet objectives that are of higher value to them. This policy dilemma illustrates difficulties with "overlapping" responsibilities between different levels of government and in designing effective special purpose programs, financed by the center and implemented by local governments.

The constraints in designing effective centrally determined special purpose programs in developing countries are legendary. To some extent these are similar to the problems in designing foreign assistance strategies that effectively reach the poorest target groups in the recipient countries - country elites may not share the altruistic objectives of donors. The issue is to design policies that build on local information, yet minimize the incentives at the local level to divert resources from the target groups. Similar issues arise in the context of foreign assistance designed to reach the poorest groups of the population, such as under the program of the Heavily Indebted Poor Country (HIPC) program.

Local governments with the most limited resources and tax bases may also have the greatest requirements for supporting the poorest groups and individuals. Thus, providing for these groups in the poorer localities may require assistance from the center. However, the center may also have concerns for the poorer groups living in the relatively well-to-do localities. 
Urban poverty, including in the richer areas, is becoming an increasing problem-in addition to the typical rural poor. Reaching these groups may not be easy, and could generate moral hazard difficulties as local officials may wish to minimize their financing of such activities and shift the burden to the center. A continuation of pockets of extreme poverty in the richer localities tends to reflect divergences of preferences between the center and local officialslocal politicians and officials may not be particularly interested in such groups-often the indigent without family support mechanisms that may not have a significant political voice.

Relatively incomplete information is available to the center on the poor and hungry without family support, as well as the budgetary operations at the subnational levels. This generates incentives for sub-national governments to divert central funds allocated for the poorest.

This paper examines the fiscal instruments available to different levels of government and their interactions to enhance the effectiveness of public policies for the poorest and hungry groups. Addressing the leakages associated with central funding and local implementation is based on the design of the programs incorporating competition for resources-both across jurisdictions and over time. This also involves moving budget processes towards greater orientation to results - together with mechanisms for intertemporal feedback in the allocation of resources in the future.

\section{B. Insights from successful programs to reach the poorest: Some examples from China and Mexico}

Depending on the circumstances, either centralized or decentralized approaches may be adopted to address the needs of the poorest. ${ }^{2}$ The options are highlighted by the experiences of two large countries-Mexico and China. Mexico has a successful central program to reach the poorest, whereas China has relied on an effective local program. Despite the successes of both programs, there are continuing challenges and difficulties in both cases. There may well be a convergence of solutions in the future-with a more significant role for the center in China, and for state and local governments in Mexico.

Mexico, which is a federal state, has effectively built a safety net on the basis of a central program - the Progresa/Opportunidades, a conditional cash transfer program that was created in 1997. The targeting has worked effectively (see Levy and Rodriguez 2004, Coady and Parker, 2002). However, the Progresa/Opportunidades model has been difficult to replicate, even in smaller countries, as administrative overheads are substantive. Also in

\footnotetext{
${ }^{2}$ Note that this paper does not provide a treatise on decentralization per se. Readers may consult Ahmad and Brosio (2006) for a review of the more recent literature in this area. The paper does not attempt a survey of targeted programs either, but uses selective illustrations to examine differing approaches to meeting the needs of the poorest groups in society.
} 
Mexico, success has been somewhat of a handicap and successive governments have added new objectives and responsibilities that make the program unwieldy and distortive. The question is whether the program with its increased remit can continue to target effectively in Mexico, and replicated elsewhere in Latin America.

In China, a unitary state, programs such as wu bao (see below) were used in the past to provide support for the poorest groups in rural areas. Such programs were predicated on locally generated information and management. With increasing inequality in China since the economic reforms of the 1990s, and dispersion in local government revenues, the issue now is whether local governments have the incentives and resources to continue to effectively provide support to the poorest groups.

Each type of program faces challenges and difficulties as described below.

\section{Centralized provision}

As mentioned, a central government might wish to carry out the social assistance program itself, with or without local identification of recipients. Given the success of Opportunidades/ Progressa, Mexican administrations have tried to use it as a compensation mechanism for different adjustment policies over time, and the remit and coverage of the program has increased significantly. At end-2005, Opportunidades covered 24 million individuals (5 million households) - roughly a quarter of the total population or 70 percent of the rural population (Levy 2006). In contrast, the Chinese programs were more tightly targeted, with the numbers of people receiving social relief in the early 1990s (including both the wu bao and the more extensive poor households support, pinkun hu) were around 6 percent of the rural population.

Another federal program in Mexico, the Seguro Popular, has also been designed to provide direct support for health care for the uninsured population. It has been criticized on the grounds that it, together with an expanding Opportunidades program, encourages an expansion of the informal sector (Levy, 2006) and poses a constraint to the orderly development of formal sector activity. This has a disincentive effect on labor markets and also limits the growth of tax revenues. Thus, these programs may perversely perpetuate the problems that a safety net should solve.

The issue of overlapping responsibilities also creates difficulties in Mexican intergovernmental finances. Whereas the Opportunidades program has been effective in meeting its initial objectives, it is seen as encroaching on a typical area of local responsibility. Indeed, given the presence of significant federal earmarked transfers for basic education and health care, states and local governments have begun to treat these areas as 
effectively the responsibility of the federal government-despite a decade long effort at decentralization.

It has proved difficult to replicate Opportunidades elsewhere in Latin America. Attempts were made, for instance, in the Red Solidaridad in El Salvador, and Tekoporã in Paraguaythese are small and homogeneous countries relative to Mexico (see Veras Soares and Britto, 2007). The centrally designed programs in these countries have involved significant administrative costs in establishing eligibility of beneficiaries and effective management. Attempts to involve local governments in the programs have not been particularly successful, as the political benefits are thought to accrue to the "central governments", whereas the political costs are expected to be borne by the localities.

In general, direct provision by the center could be achieved with relatively broad targetingalbeit at a fiscal cost, leakages to the less poor. It may be more efficient to design mechanisms that better utilize the information available to local governments (including at the community level), but with the center equalizing the capacity of the relevant level of governments to undertake the projects. But would the local governments have the appropriate incentives to do so?

\section{Local provision}

A good example of local identification and provision for the poorest is from rural China. Since the establishment of the Peoples Republic, a key element in reaching the poorest was the mechanism known as wu bao, or five guarantees. It related to a minimum provision of food, health care, shelter and clothing and funeral costs for all citizens-hence the term 5 guarantees. Its operation is based on local (often village or community-based) information to identify the poorest groups in society without extended household support, particularly in rural areas where the reach of formal social security instruments is at best limited. As is evident, the $w u$ bao families and individuals are often among the poorest (Ahmad and Hussain, 1991). Over time, the term came to denote a special category of persons-those unable to earn a living and lacking relatives for support. These are predominantly the orphans and elderly or disabled, without family support. As is clear, the identification of the vulnerable without family support has to be based on local knowledge. Such individuals tend also not to be associated with elites or interest groups that often have an interest in "capturing" resources accruing to the localities.

The social protection mechanisms in China are undergoing significant change. While the market-orientation of the past decade has brought about rapidly rising real incomes, particularly for families able to participate in the labor market, it has generated greater vulnerability for some of the poorest. The social protection system has come under strain as the resources available to lower level local governments, particularly in the poorer regions, 
have been subject to greater constraints. On the one hand, there has been a recentralization of the main sources of revenue, and on the other, additional spending responsibilities have accrued to lower levels. Thus, the resources available to provide support or social assistance to the poorest, including the $w u$ bao, tend to vary by localities. Moreover, with growing inequalities, "local capture" may begin to be a problem in China, as it is in other parts of the world (see Bardhan and Mookherjee, 2000, 2006).

A more recent intervention, the $D i B a o$, is a largely urban program providing conditional cash transfers to individuals below the poverty line. It started in 1999 and now provides support to around 22 million people, or 6 percent of the urban population (Ravallion 2007) or roughly the same magnitude as the rural anti-poverty programs (wu bao and pinkun hu). Local governments select recipients, and co-financing is available from the center. Central financing varies by province-from zero in the rich coastal regions to 100 percent in Tibet. In principle, the program encompasses two key characteristics: (1) local identification of need, with (2) a degree of equalization in the financing arrangements. Ravallion (2007) however finds that, despite the central "equalization", the richer localities are able to support higher income levels for program eligibility than poorer ones.

The policy design issues in China are complicated by its multi-tiered administration, in which nested budgeting decisions are made-the center decides how much to allocate to a given province, which then decides on allocations to prefectures, which make transfers to counties and then sequentially down to townships. Allowing the localities to determine eligibility criteria puts the onus on the localities, but at the possible cost of excluding some of the deserving poorest. Tighter central determination of eligibility would move the di bao closer to the opportunidades model, although still relying on local identification and administration. This could also make the costs to the center open-ended and does not preclude diversion of centrally provided funds.

In the policy options that follow-we examine decision making in large multi-level countries (reflecting both Mexico and China) based on work by Ahmad, Tandberg and Zhang (2002), and also look at the budgeting model that might be relevant in minimizing leakages (Ahmad and Martinez, 2004).

\section{The policy options}

An ideal system of transfers would involve clearly identified criteria provided by the center to local governments to assist them in looking after the poorest (Ravallion 2007). But, for overall budgetary constraints and efficiency of spending, this requires that local governments disclose information accurately on the extent of need, and also not divert central funds to other uses. It is not clear that they face the incentives to disclose this information-on the 
contrary the localities may distort the information in order to maximize transfers from higher levels.

Thus, central governments face a dilemma. Reaching some of the poorest requires local information for effective identification and targeting. This cannot be obtained without the cooperation of local governments. Direct central provision is possible but requires administrative capabilities and resources, and may generate negative effects, such as incentives to remain in the informal sector. Local governments may have the information, but the poorer ones lack the financing to carry out the functions, and in the "game" with the center, may lack incentives to effectively use central transfers.

\section{Financing instruments for social programs}

In this section, we use insights of the new political economy literature on intergovernmental finances (see Lockwood, 2006 for a survey) to examine options for improved provision of public services for the poor. This involves the design of taxes at the sub-national level, and equally important appropriate transfers. The interaction of instruments matters, as does the budgeting framework, especially the use of contracts together with new multi-year budgeting techniques that focus on the "results or outcomes" of specific programs. These mechanisms build on regional and intertemporal competition, even if there are overlapping responsibilities.

Each issue is discussed sequentially below.

\section{Tax instruments}

A key element in accountable self-governance at the sub-national level is access to ownsource revenues at the margin, so that a jurisdiction is able to raise additional funds needed for its key local spending. This is also a fundamental precondition for the establishment of hard-budget constraints at the sub-national level, without which no-bailout conditions are barely credible (Ambrosiano and Bordignon, 2006). However, whether or not a local jurisdiction has incentives to use its own-tax handles is heavily influenced by transfer design-if a local government could rely on transfers rather than own-source revenues, it probably will, with resulting erosion in accountability. This has been the recent experience in Mexico.

Another drawback with primary reliance on local tax bases is that these tend to vary considerably, especially in large countries. For instance, in Mexico, the Federal District accounts for roughly half of all property tax collections-which are in any case low even by Latin American standards. Thus, with considerable local variation in revenue bases, and limited or no control over rate structures, the responsibility for providing a modicum of 
social services, especially in the poorer regions, generally passes to the higher levels of government.

Table 1 Sources of Tax Revenues of Local Governments in Selected Federal Countries, 2001 (percent of total revenue)

$$
\text { Country }
$$

Payroll
tax

Property
tax

General
consumption
$\operatorname{tax}$

$\begin{array}{lrrr}\text { Australia } & 0 & 0 & 100.0 \\ \text { Austria } & 37.7 & 19.1 & 10.0 \\ \text { Belgium } & 85.8 & 0 & 0 \\ \text { Canada } & 0 & 0 & 91.6 \\ \text { Germany } & 77.1 & 0 & 16.6 \\ \text { Mexico } & 0 & 0.1 & 88.5 \\ \text { Switzerland } & 83.1 & 0 & 16.6 \\ \text { United States } & 6.2 & 0 & 71.5\end{array}$

Source: Ambrosanio and Bordignon 2006.

There is a tendency to administer centrally the broadly based taxes, such as the VAT and the corporate income tax, as in Mexico in the late 1980s, where a number of state level taxes were abolished on efficiency grounds to make "fiscal space for a centrally administered VAT." The states effectively ceded their tax bases to the center for guaranteed transfers. Also in China in 1994 the establishment of a VAT to be administered by a central State Administration of Taxation was a critical element of the fiscal reforms. More recently, in Australia a range of state taxes were replaced by a VAT, which is administered centrally although all revenues collected are redistributed to the states through the Commonwealth Grants Commission.

In all cases, transfers have been established to compensate for the loss of sub-national revenues (particularly state or provincial sales taxes among others) eliminated as a result of the establishment of the VAT. In China, the equalization transfer introduced in 1994 has gradually increased in importance as additional funds have been made available. Mexico had a complex system of untied and earmarked transfers, but did not have an equalization framework. The weak own-source revenues of the lower tiers of government, and limited accountability, together with an opaque and complex transfer design probably explains why a central program in Mexico has been its most successful poverty reduction instrument. Lower level of government lack the incentives or financing to effectively replicate Opportunidades at the sub-national level.

Figure 1 Property tax collections in Mexican States (Pesos) 


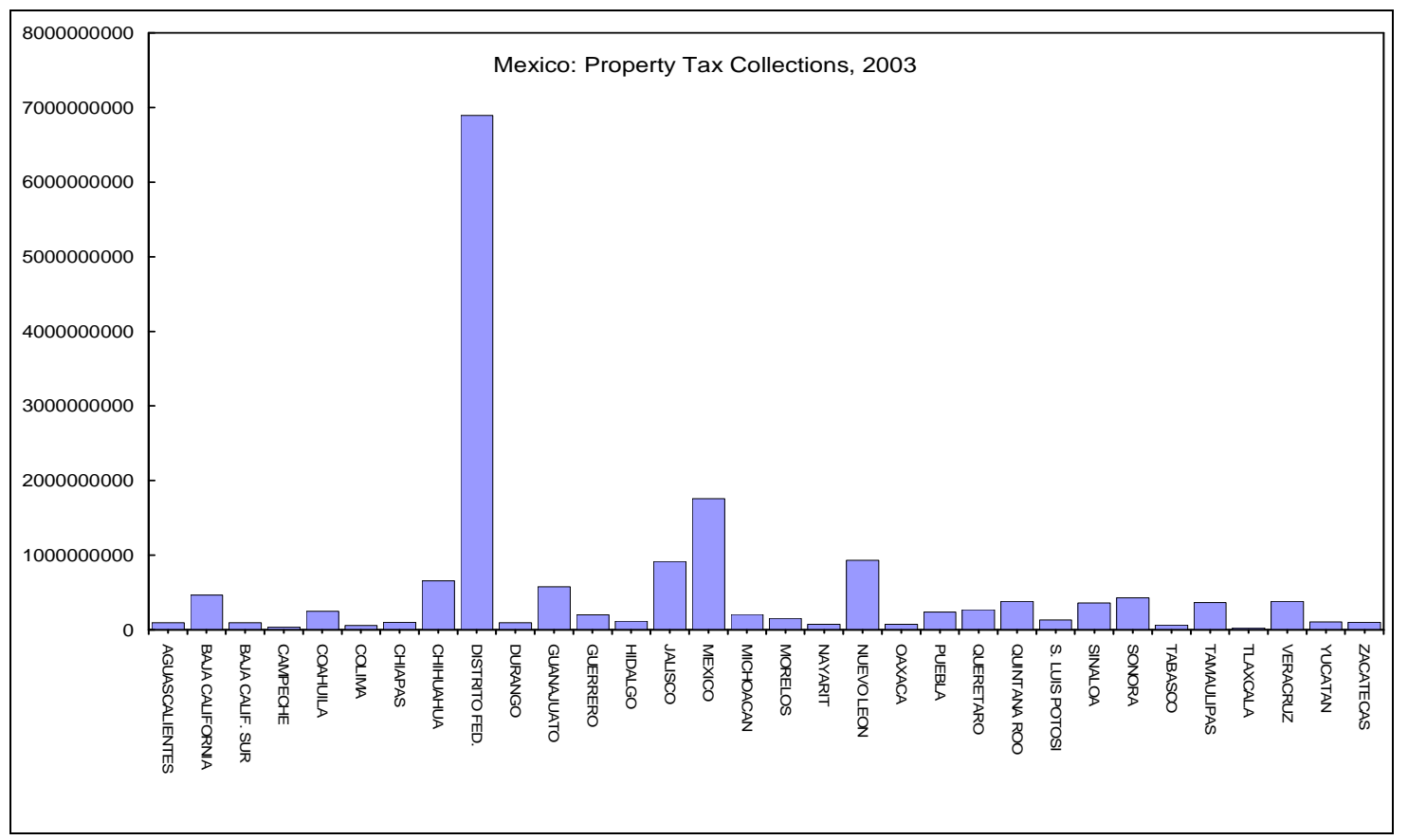

States (including the Federal District)

\section{Transfer design}

The central government may try and equalize fiscal capacities, as has been the case in many OECD countries, such that each local government has the capability of providing similar levels of services at similar levels of fiscal effort. This is the basis for equalization transfers in countries like Australia (see Ahmad and Searle 2006).

The principles of the Australian system-focusing on spending needs and revenue capacities has been adopted in China, and resources available for equalization resources are gradually being increased (Ahmad, Li and Richardson, 2002). Information flows and the political process are important in ensuring that local officials are held accountable for the use of untied funds. Thus, in less developed countries where information flows are problematic and incomplete, there may not be adequate moral suasion to ensure that the basic services are actually provided at the sub-national level with sole reliance on "equalization transfers."

Alternatively, the center may choose to provide such services directly or through special purpose transfers designed to finance local provision of public services, say education or health care. This is the typical case, but it does not guarantee that the poorest will be reached, 
as the execution is typically by sub-national governments. The difficulty is that any earmarked transfer from the center imposes a constraint on the local government. Matching arrangements have been used extensively in some advanced countries, especially the United States, in order to get some "buy-in" from the local governments. However, in developing countries, need is likely to be higher in the poorer localities with weaker sources of ownrevenues. Hence, establishing matching criteria might actually exclude some of the poorest localities, and hence deserving recipients.

The linkages between transfer design and accountability as well as incentives to raise ownrevenues and manage spending efficiently are complex but very important. Typically, a range of transfers are used for different purposes. If the center also includes "gap-filling" deficit financing among the set of transfers, this could vitiate any of the other "incentives" to ensure accountability of local officials (Ahmad and Searle, 2006).

\section{How to make special purpose transfers work?}

Can adequately targeted expenditure programs be designed that are financed by the central government but implemented by the local governments to minimize the incentives of local governments to divert central transfers for their own objectives? This has been a perennial problem in China, for example in ensuring minimum standards in education (e.g., number of years of schooling). Can communities determine priorities and monitor implementation? At the one extreme, there is a danger that funds could be diverted, and at the other that unfunded mandates might be created - in both cases it is possible that services would not be provided effectively. Moreover, the priorities may not reflect the interests of the poorest, particularly the most vulnerable members of society without sources of family support-the benefits from the transfers might accrue largely to powerful interest groups or officials.

The central government's (or donors') problem is to design appropriate targeted or special purpose transfer programs to meet the needs of the poorest but executed by recipient agencies (or subnational governments). ${ }^{3}$ The objectives of the center and the recipient governments are often likely to be different-the recipients may have less concern with providing for the poorest as the responsibility for these groups may effectively lie with the center. In any case, the recipient local governments receiving funds, in the absence of full information, could use these for other purposes without significant penalty in the traditional single period budgeting framework.

\footnotetext{
${ }^{3}$ A similar problem exists when an international agency or donor country provides financing for special purposes to be implemented in a recipient country.
} 
Ahmad, Tandberg and Zhang (2002) model a three-tier hierarchical structure of government that may be relevant for large countries such as Mexico or China: the central government is at the top level of the hierarchy, several provincial (state) governments in the middle layer, and a few local or county-level governments within the administrative area of each of the provinces. The interest of leaders of provincial and local governments is to maximize perquisites and their overall budgets.

The central government sets aside a certain amount of financing for specific programs to be carried out by the localities. Ahmad, Tandberg and Zhang (2002) assume that the central government cannot contract directly with the localities, due to high-transaction costs or political reasons.

The interaction between the provincial and local governments is nested in the central selection process. Prior to the submission of its bid, the provincial government arranges a bidding process among its localities. Each county within the province offers a bid proposal. The provincial government selects one and formulates the provincial proposal based on the selected local proposals. If the province wins the program in the central selection, it will receive the amount equal to its budget bid. Then the provincial government decides the proportion of the budget to be allocated to the locality, to carry out the program. The local government then determines the effort level it will exert to implement the program. This subsumes "local capture" or other diversion of funds, and is not directly observable by the higher levels of government.

Figure 1 presents a simplified decision diagram of the three levels of governments. The analysis is similar to the classical "prisoner's dilemma." It is generally not possible to obtain an efficient solution in a one-period game of this type. Unless the game is repeated or constricted in some other way, officials in transfer receiving jurisdictions will take decisions that are individually rational but which lead to suboptimal solutions and may not meet the objectives of the donor governments. There must be multiperiod interactions among the different levels of government. If the game is of only one period, the local governments will bid as low as possible to obtain the transfer; and may not effectively implement the scheme. In a multi-period game, where the governments care for their reputation in the future, it may be possible to identify low-cost agents, and to limit the possibility for a diversion of funds or inefficient implementation.

In order to mitigate problems of asymmetric information, there must be some element of competition between the different governments at the same level. There should be more than one province bidding for the program in the central selection, and more than one locality in the provincial selection. To avoid moral hazard, the transfer scheme must include elements of punishment and rewards from the higher administration to the lower levels of government, based on the evaluation results of the final outcome. This serves 
as either carrot or stick through its impact on the agents' probability of winning future programs. The scheme also provides a "learning mechanism," where the outcomes in one period have an impact on the central government's assessment of the abilities of lower levels of government to meet their objectives in subsequent periods. Indeed, "reputation" in one set of observable programs might be used as proxy for likely effectiveness in program implementation in general-although there may be more incentive for local governments to implement investment projects rather than provide support to the indigent.

In order to be able to select the program bids through a competitive process, the central government must be able to define the specification of programs very precisely, and to monitor the degree of compliance against these specifications. The objectives of the program should be measurable, standardized across the localities, and involve as little subjective judgment as possible. After implementation, it should be possible to evaluate whether objectives are achieved with minimal ambiguity. Unless these conditions are met, agents may be able to influence the central governments' selection of program sites by providing substandard services in areas that are insufficiently defined in the program specifications.

Key elements of the scheme (consistent with what is observed in reality) are that the central government is able to set the policy agenda and also that it is able, in principle, to cut off funds for non-compliance with agreed conditions. However, threats to cut off funds for the poorest groups may not be credible, especially given the overlapping responsibilities found in China or Mexico, but cross-conditionality involving threats to cut off investment funding strongly desired by local officials may be effectively utilized. 
Figure 1. Decision Diagram for the Three Tiers of Governments

\section{Central Government}

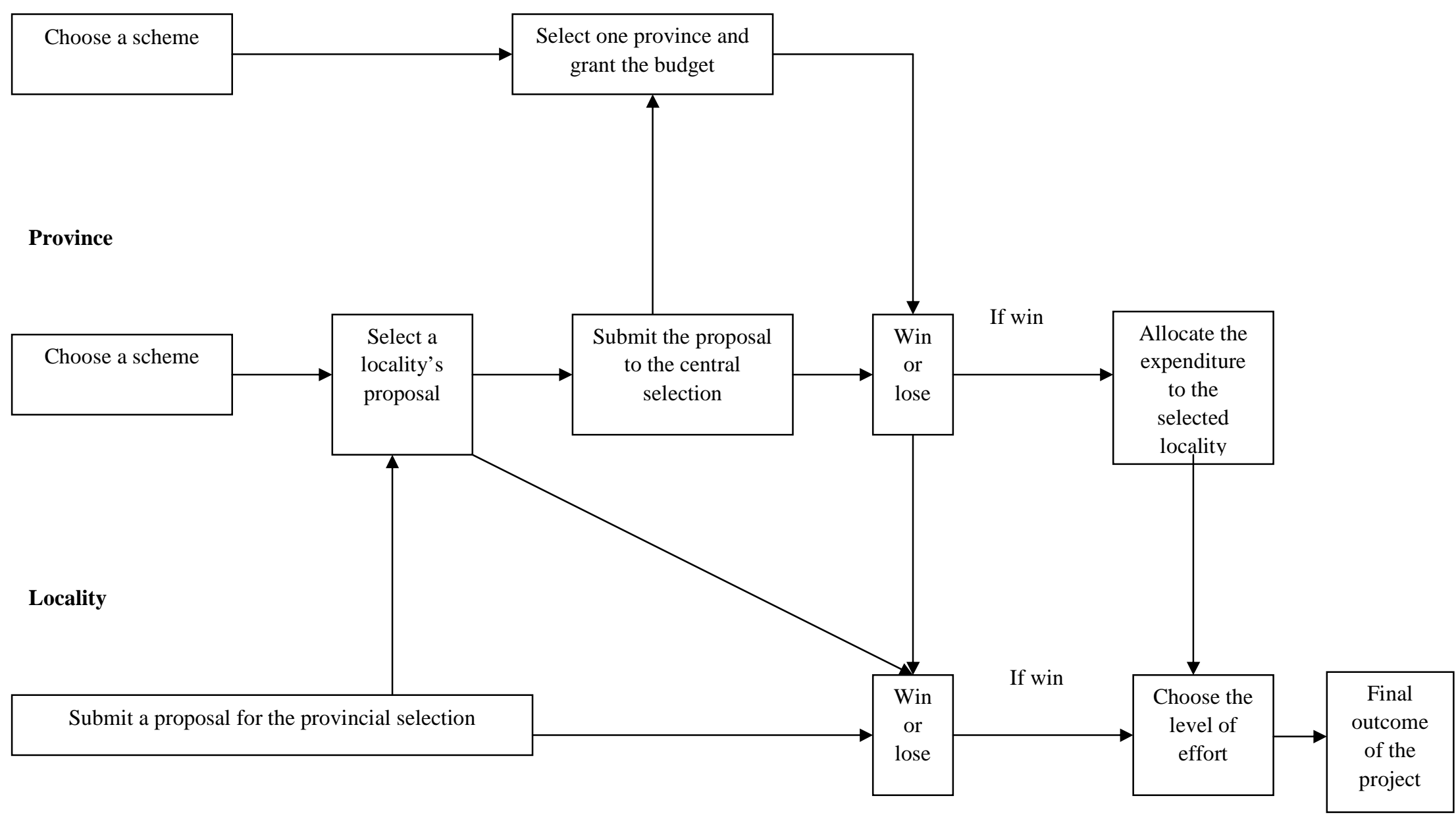


The design of policy to provide support to the poorest groups would involve crossconditionality, where outcomes for provision for the poor could be built into the agreement or contract for investment funds for the localities. Thus, by virtue of setting the agenda, the center can ensure that resources are adequately used for the poorest by threatening to withhold funds for projects or investments that are evidently within the preference function of the localities.

A central result is for future transfers to be made conditional on policy reforms or on past performance. In practice, however, funds distributed by the central government are often independent of the past success of the program-given the typical single year budgeting framework with little feedback based on outcomes. In many cases, there is an incentive for a donor government to continue to give transfers for the program, not just because of incomplete information, but because funds that are not distributed might lapse. This places the emphasis on clearly identifying "outcomes" of policy actions that could be monitored, and in ensuring that future budgets are linked to the achievement of the outcomes-in a repeated game perspective. In more advanced cases, this has led to the development of "contract federalism," (see Spahn, 2006). The findings of the model echo those from the foreign aid literature. Svensson $(1999,2003)$ suggests that the donor government's ineffectiveness in providing incentives to improve the performance of targeted expenditure programs may be the consequence of a time-consistency problem.

A policy option is to increase the effectiveness of targeted expenditure programs by introducing competition among local governments in different districts and across time. This formulation echoes the recent developments in the fiscal federalism literature that based efficient outcomes on enhanced competition (Breton, 2002, Ahmad and Martinez, 2004)). This allows the central government to distribute all the available transfers and is shown to solve the time-consistency problem described before. The funds that local governments will receive depend implicitly on the central government's confidence in their ability to use these effectively. Therefore, even without explicit contracts, a local government may be induced to consider the central government's interests when deciding on its own actions. This increases the local government's likelihood for receiving more transfers in the future. In a one-period game approximating an annual budget process, recipient governments have incentives to cheat. Horizontal competition helps but is not sufficient to eliminate incentives to cheat.

A combination of both horizontal and intertemporal competition eliminates incentives to divert resources from the objectives of the central government. The competition elements have implications for the information flows and budget models that might be relevant to ensure that funds for programs to reach the poorest are not diverted to other uses. 


\section{Budget processes and transparency: ensuring accountability}

The flow of standardized information is critical in providing a basis for evaluating how monies are used within and across jurisdictions. This involves the establishment of a common structure for the budget classification, e.g., based on the IMF's standard for the economic classification: the Government Financial Statistics Manual 2001 (GFSM2001) and the UN's classification of the functions of government. These need to be harmonized across all jurisdictions. In addition, most advanced countries use systems of Treasury Single Accounts to manage and track the government's cash. In multi-level countries, it is also critical to set up standards for disclosure and reporting by sub-national governments. These requirements are described in Ahmad, Albino-War and Singh, 2006).

Efforts to establish all of these requirements for information flows are underway in China, but are only beginning in Mexico. In both countries, the immediate issue remains to formulate policies and implementation plans in the context of incomplete information on the use of funds. To some extent, the use of multi-year budgets and competition for the use of funds across local governments and over time should be feasible in the relatively short term, even if the main public financial management reforms are likely to take time to implement fully.

Attempts by central governments to introduce performance budgeting at all levels of government, without adequate systems to track and account for financial flows, are unlikely to be very successful. Indeed, experience has shown that this may even delay the basic information building blocks that are needed in the longer term. Without standardized information that can be used by households to compare performance across jurisdictions, and to use this to discipline local officials, it is not clear that reliance on citizens' action groups and communities to self-police spending will be sufficient to prevent misuse or divergence of funds, except perhaps in egregious cases.

The longer term goal must remain to establish standards for information flows and reporting that lead to transparency across and within governments. These are critical in achieving accountable operations at all levels of government. However, an immediate measure that can be implemented in most cases is to begin to use feedback mechanisms in the budget process system that take into account the effects and outcomes in meeting the needs of the poor.

\section{E. Policy Implications}

Direct central provision of programs to support the poorest may be feasible in some countries, but may pose significant administrative difficulties in most countries. Local design and implementation uses the advantage of local information-but the variance in resource levels across localities in large countries may make it essential for there to be some central transfers for the poorest. The difficulty is that with central earmarked transfers, recipient governments have incentives to divert resources. 
The typical one-period budget process encourages inefficient use of central transfers, even if diversion is not intended. The central government would generally like to make transfers conditional on policy reforms or past performance. One of the key policy implications is that a multi-year budget framework, including multi-year appropriations, would greatly facilitate the achievement of central government objectives, since this opens up the possibility of intertemporal competition across lower level jurisdictions. Within-year and intertemporal competition across lower level governments is important in mitigating the problems of asymmetric information. This also helps in controlling costs and ensuring efficiency in spending.

Cross-conditionality in the design of transfers is important to address political economy issues. Threatening to withhold funds for the poorest groups of society might not be credible. However, it is feasible to withhold investment funds if the poverty-reduction objectives are not met. This cross-conditionality affects elements that are generally important in the preference functions of local officials and politicians.

The central government must define precisely the specifications of programs and the conditions to be met, and to monitor the degree of compliance against these specifications. While it might take time to establish proper government financial information management systems at all levels of government - this applies to Mexico as well as to China, both outputs and outcomes should be defined carefully to prevent misuse or misallocations of resources.

It would also be helpful to be able to draw up actionable contracts between the center and the local governments. Given that the allocation of inputs is not easily observable, as far as possible the contracts should be able to specify identifiable outputs (even if the outcomes may not be simple to specify or monitor in many developing countries).

In more advanced countries, there may be a possibility of moving towards performance budgeting at all levels of government, although the preconditions for this are quire demanding. But, in the short-run, there is considerable promise in clarifying responsibilities, defining outcomes and using targeted transfers within a multi-year budgetary context. 


\section{References}

Ahmad, Ehtisham and Giorgio Brosio, eds., 2006 Handbook of Fiscal Federalism, Edward Elgar.

Ahmad, Ehtisham, Maria Albino-War and Raju Singh, 2006, "Subnational public financial management: institutions and macroeconomic considerations," in Ahmad and Brosio (2006, op cit).

Ahmad, Ehtisham, Li Keping and Thomas Richardson, 2002, "Recentralization in China?," in Ehtisham Ahmad and Vito Tanzi (2002), (eds.), Managing Fiscal Decentralization, Routledge.

Ahmad, Ehtisham, Eivind Tandberg, and Ping Zhang, 2002, "On National or Supranational Objectives: Improving the Effectiveness of Targeted Expenditure Programs," IMF Working Paper 02/209 (Washington: International Monetary Fund).

Ahmad, Ehtisham and Leo Martinez, 2004, "On the Design and Effectiveness of Targeted Expenditure Programs," IMF Working Paper (Washington: International Monetary Fund).

Ahmad, Ehtisham and Athar Hussain, 1991, "Social Security in China," in Ehtisham Ahmad, Jean Drèze, John Hills and Amartya Sen, eds., 1991, Social Security in Developing Countries, Clarendon Press: Oxford.

Ambrosiano, Flavia and Massimo Bordignon, 2006, "Normative versus positive theories of revenue assignments," in Ehtisham Ahmad and Giorgio Brosio (2006).

Bardhan, Pranab and Dilip Mookherjee, 2000, "Relative Capture of Government at Local and National Levels," American Economic Review, Vol. 90 (2), pp.135-139.

Bardhan, Pranab and Dilip Mookherjee, eds., 2006, Decentralization and Local Governance in Developing Countries - A Comparative Perspective. MIT Press: Cambridge.

Besley, Tim and Ravi Kanbur, 1993, "The principles of targeting," in Michael Lipton and Jacques van der Gaag, eds., 1993, Including the Poor, The World Bank, Washington DC.

Birner, Regina, 2007, "Decentralization and Public Service Provision - How to Meet the Needs of the Poorest?" Paper presented at a conference on Effectiveness of Public Service Delivery, Moncalieri, Italy. 
David Coady and S. Parker (2002), "A cost-effectiveness analysis of demand and supply-side education interventions: the case of PROGRESA in Mexico," Discussions Paper 127, IFPRI.

Levy, Santiago, 2006, Productividad, crecimiento y pobreza en México: Que sigue después de Progresa-Oportunidades?, IDB.

Levy, Santiago and Evelyne Rodriguez, 2004, Progresa-Oportunidades, InterAmerican Development Bank.

Lockwood, Ben, 2006, "The political economy of decentralization," in Ahmad and Brosio (2006, op cit.).

Ravallion, Martin, 2007, "Geographic Inequity in a Decentralized Anti-Poverty Program: A Case study for China," processed, The World Bank: Washington DC.

Seabright, Paul, 1996, "Accountability and Decentralization in Government: An Incomplete Contracts Model," European Economic Review, XL, pp. 61-89.

Spahn, Bernd, 2006, "Contract Federalism," in in Ahmad and Brosio (2006, op cit.).

Svensson, Jakob, 1999, “Aid, Growth and Democracy,” Economics and Politics, III, pp. 275-297. ,2003, "Why Conditional Aid Does Not work and What can be Done About it?" Journal of Development Economics, LXX, pp. 381-402.

Veras Soares, Fábio and Tatiana Britto, 2007, "Confronting Capacity Constraints on Conditional Transfers in Latin America: the cases of El Salvador and Paraguay," International Poverty Center, Working Paper No. 38 (Brasilia: UNDP).

Von Braun, Joachim and Ulrike Grote, 2002, "Does decentralization serve the poor," in Ehtisham Ahmad and Vito Tanzi (eds.), Managing Fiscal Decentralization, Routledge. 